\title{
The EU Is More Than A Constraint On Populist Democracy
}

Jan Komárek

2013-03-25T08:27:11

Jan-Werner Müller's eloquent proposal on what the EU should do when one (or more) of its Member States seems to be sliding towards authoritarianism follows the logic of the idea of constrained democracy, put forward in Müller's recent work on the history of political thought in the $20^{\text {th }}$ century Europe. While I find this vision of the EU appealing (and find Müller's work on the EU deeply inspiring), I do not think that it is based on a faithful reconstruction of the integration process and the accompanying 'post-war constitutional settlement'. I fear that Müller's idealisation, no matter how well it is meant, harms the true EU democratic potential. Moreover, his proposal to establish the 'Copenhagen Commission' only confirms that the current EU is not capable of defending democracy and the rule of law.

Below I firstly criticise the notion of 'constrained democracy' and its extrapolation to the EU. Then I reconstruct what the integration actually is and can potentially be. Finally, I will argue that it is the Commission's role to step in now, if it believes that the ongoing constitutional reforms in Hungary violate Article 2 TEU values. The establishment of the 'Copenhagen Commission' is the familiar, but repeatedly unsuccessful EU strategy of creating a new institution rather than its addressing the real problem.

\section{European integration: constraining and enabling at the same time}

Jan-Werner Müller derives the legitimacy of the EU's intervention on from his understanding of European integration as an extension of the idea of 'constrained democracy'. This idea found its home in post-war Europe, expressing the deep distrust of popular sovereignty, coupled with the drive towards delegation to unelected institutions in general. According to Müller, constitutional courts are a prime example of such delegation and European integration is 'part and parcel of this comprehensive attempt to constrain the popular will' since it 'added supranational constraints to national ones'.

While this is an appealing presentation of the integration process, it is based on its strong idealisation rather than a faithful reconstruction. Its major flaw consists in its focusing on the political ideas while their economic dimension is left completely aside. In reality, democratic and fundamental rights concerns were quite explicitly omitted from the structure of the original communities after the fiasco of the project on the European Political Community in 1953. It is telling that in his book Müller invokes Andrew Moravcsik's analysis of the origins of international human rights regimes in order to support his argument, while Moravcsik's piece is devoted to the 
analysis of the negotiation of the European Convention - to which the EU always had - and many people will agree that still has - a rather ambivalent attitude.

Rather than functioning as a fundamental rights constraint on popular sovereignty in the Member States, the EU allowed avoiding the vicissitudes of politics when different economic policies were implemented. This is powerfully demonstrated by the recent book by Chris Bickerton on the process of the transformation of national states into EU Member States. Particular ideologies behind the integration process differed and ranged from the economic planning of the ESCS of the early 1950's through the ordo-liberal structure of the EEC's rules on free movement and competition, to the entrenchment of the neoliberal ideology in the Single European Act and the EMU. What they had in common was the circumvention of and later constraint on domestic political process through integration. This integration constraint was however radically different from that imposed by liberal national constitutions internally. While the latter put an individual and her dignity at the centre (which has its own problems to be sure), the former was always concerned with economy and the abstract ideal which particular ideology of the time presented.

There is yet another difference between the constraint on popular sovereignty adopted by national constitutions and the integration one. National constitutional constraint is re-negotiable by those affected by it. It is a mistake to see the process of constitutionalisation of post-war politics solely in terms of the empowerment of courts. They were empowered, to be sure, but they have never become 'supreme' or 'final' in the sense usually connected with the American notion of judicial supremacy. One must not neglect the possibility of constant political contestation, which constitutional courts cannot foreclose by their decisions: European constitutions can be 'and often are' amended and constitutional courts are deeply entrenched in the political systems of their countries. They are thus responsive to the concerns of the people (let alone the fact that judges are themselves part of that 'people'). This is how the notion of constitutional democracy should be understood: putting various institutions into a common structure of mutual involvement and communication.

The integration constraint imposed on Member States by their membership in the EU is different: there is little, if any possibility to engage in the same kind of re-negotiation that exists on the national level. This is the lesson we know ever since Fritz Scharpf draw the distinction between positive and negative integration, if the political process at the level of the EU is to be activated. There was also little, until recently, political mobilisation against the integration constraint in the Member States. The public protest against austerity policies can mark the coming of 'European spring' called for recently by Ulrich Beck.

\section{European integration as a constitutional democratic project}

Yet, my contribution does not want to be another 'coldly realist' voice from the UK, limiting the integration project to economic ends. After the Enlargement in 2004 and 2007 the normative structure of the EU has decidedly changed. To say that the EU 
is no more a peace project, as David Cameron recently did in his 'Europe speech', is to ignore the recent history of mass killings at the heart of Europe and to neglect the complex history of continental Europe in general. When Croatia joins the Union, the experience of war will again be part of the living memory of some European citizens. The EU thus has a mandate to constrain the Member States precisely in the way suggested by Müller. This is how many people in post-communist Member States understand the role of the EU today.

It is however only a part of the story: the EU is also enabling -and in this respect Müller's account remains deeply unsatisfactory. It leaves the question of what it is that the EU enables (or can enable) without examination.

These can be nice things, such as the possibility of individual citizens to realise their life projects on a greater scale (to go to another country and be accepted on equal terms), or the possibility of individual Member States to address problems that they do not have the capacity to solve. Taming global financial markets in the interest of its citizens is a case at point. In this sense it can be seen as a constitutionaldemocratic project: extending both individual and political autonomy of EU citizens.

The EU enables things we might not like, however. It creates inequalities between those who can benefit from the movement across borders and those who cannot, while it can at the same time inhibit compensatory redistribution at both national and EU level. Think of the cases which allow mobile (translate as rich and welleducated) patients to seek the best medical treatment available, while the costs of such treatment is bore by their fellow citizens in the state of origin - including those who do not have the capacity to move to another country. Or the ECJ's continuous dismantling of the national welfare state - while the creation of its substitute at the EU level seems increasingly improbable (see eg. this analysis).

This is not a cry that EU is not democratic and hence does not have legitimacy to intervene in countries like Hungary. The argument pursued here is different: in my view, there is a great potential for the EU to be democratic in some meaningful sense, in fact much wider than that suggested by Müller; alas, it actively denounces such option. How else can one read the measures adopted since the eruption of the Euro(zone) crisis? The EU in fact assists in dismantling democracy in (some) Member States through circumventing national parliaments and their European counterpart. The integration constraint thus serves again to mute real concerns of European citizens, while the handling of the crisis suggests that the EU wavers between taming financial markets and taming peoples' concerns about the levels of inequality exacerbated by the promotion of the latter.

\section{Why the 'Copenhagen Commission' is not a good idea}

The foregoing can seem as a particularly pessimistic account of the integration process. However, Müller's proposal in fact reinforces the present diagnosis: it sends a message that it is not for the current EU to deal with situations such as the one in 
Hungary or Romania. A new institution must be established, which is of course the familiar European way of dealing with its problems: institutional self-aggrandizement.

I propose instead that if the Commission believes that the governments of Hungary or Romania violate the EU fundamental values it should start an infringement action against these countries. By infringements action I do not mean actions limited to the existing EU legislation, as we saw in these instances. Müller is quite right: translating the Hungarian Government's attack on the independence of the judiciary by forcing a significant number of judges out of office into an issue of age discrimination sends a wrong message. Instead, the notion of 'an obligation under the Treaties' contained in Article 258 TFEU should be understood as encompassing the respect for the EU foundational values.

This option strikes the right balance between the 'nuclear option' of Article 7 TEU procedure and the unrealistic proposal discussed on this blog few months ago: the empowerment of European citizens by a 'reverse Solange doctrine' (unrealistic simply because it does tell how a citizen's case based on a more generous interpretation of the scope of application of EU fundamental rights can ever reach the ECJ - procedurally). Infringement action does exclude the government in question from EU politics (as Article 7 TEU procedure ultimately does), but through the possibility to impose financial sanction goes farther than a mere declaration and imposes real political costs on the government in question.

Müller rejects the Commission's involvement on grounds that it runs against the recent attempts to politicize it. Leaving aside the fact that such attempts would still need to be realised, more importantly, I do not think that the politicisation of the Commission should lead ignorance of the EU fundamental values or the lack of credibility in that respect. Quite to the contrary: these are too important things to be left to lawyers-experts, however wise.

(cc) $\mathrm{BY}-\mathrm{NC}-\mathrm{ND}$ 